\title{
PENETRATION AND WETTABILITY OF VARNISH IN THE WOOD OF Cryptomeria japonica
}

\author{
Ana Paula Namikata da Fonte ${ }^{1 *}$, Mayara Elita Braz Carneiro ${ }^{2}$, Graciela Inez de Bolzon Muniz $^{3}$ \\ ${ }^{1 *}$ Federal University of Paraná, Department of Forest Science, Curitiba, Paraná, Brazil - ana.namikata@ gmail.com ${ }^{(*)}$ \\ ${ }^{2}$ Federal University of Paraná, Department of Forest Science, Curitiba, Paraná, Brazil - mayaraecarneiro@ gmail.com \\ ${ }^{3}$ Federal University of Paraná, Department of Forest Science, Curitiba, Paraná, Brazil - gbmunize@ufpr.br
}

Received for publication: 02/02/2018 - Accepted for publication: 23/04/2018

\begin{abstract}
Wood products require preservative and finishing treatments in order to raise their quality and market value, thus making their appearance more pleasing and their strength higher. The objective of this study was to analyse the wettability of different finishing processes, as well as the penetration of products in the wood of Cryptomeria japonica through Scanning Electron Microscopy (SEM). To observe the behaviour of the sessile drop, the present study used SEM with two replicates per sample and a Goniometer with five replicates per sample for each radial position, totaling 30 samples per varnish (copal, water-based, nitrocellulose, and polyurethane) and 120 in total. It was concluded that the water-based varnish presented higher penetration when observed in the SEM and the polyurethane varnish formed a film thicker than the other treatments on the substrate. Copal varnish and polyurethane showed higher hydrophobicity and higher resistance to moisture.

Keywords: Cell structure, penetration of finishing, finishing.
\end{abstract}

\section{Resumo}

Penetração e molhabilidade do verniz na madeira de Cryptomeria japonica. Os produtos de madeira necessitam de tratamentos preservativos e de acabamento para elevar sua qualidade e valor de mercado, tornando assim sua aparência mais agradável e sua resistência mais elevada. O objetivo deste trabalho foi analisar a molhabilidade dos diferentes acabamentos, bem como a penetração dos produtos na madeira de Cryptomeria japonica por meio da Microscopia Eletrônica de Varredura (MEV). Para observação do comportamento da gota séssil, o presente estudo utilizou a MEV com duas repetições por amostra e um Goniômetro com cinco repetições por amostra e por posição radial, totalizando 30 amostras por verniz e 120 no total. Concluiu-se após os resultados que o verniz a base d'água apresentou penetração superior quando observado no MEV, e o verniz poliuretano formou uma película sobre o substrato mais espessa do que os demais tratamentos. O verniz copal e o poliuretano apresentaram maior hidrofobicidade e maior resistência à umidade.

Palavras-chave: Estrutura celular, penetração do acabamento, acabamentos.

\section{INTRODUCTION}

Finishing is used to value the original characteristics of wood by making its appearance more attractive, as well as protecting its surface (SOUZA et al., 2009; SOFUOGLU; KURTOGLU, 2014). The quality of machining and finishing is influenced by properties of wood (CSANÁDY et al., 2015). According to Williams (2010) and Rowell (2012), properties attached to the surface of the substrate and the cellular structures in the wood affect the application and quality of the film.

In addition, anatomical characteristics may influence the performance of varnishes, since some species have higher porosity, for example, and thus absorb a greater amount of product, requiring the application of a higher number of layers of varnish. Since finishing emphasizes the aesthetic aspect of the wood, superficial irregularities of the wood tend to be highlighted by the application of varnishes. For this reason, it is important to prepare the surface, softening its imperfections with processes of sanding and planning (WATAI, 1995; COELHO et al., 2008; SOUZA et al., 2009).

In terms of products for finishing, polyurethane is considered to be very resistant to abrasion, staining, heat, and humidity, but it does not allow repairs and has application difficulties (ÇAKICIER et al., 2011). Another product widely used on wood surfaces is nitrocellulose-based varnish, which is advantageous in terms of durability and flexibility. However, it can present flammability,

FLORESTA, Curitiba, PR, v. 49, n. 1, p. 117-124, jan/mar 2019.

Fonte. A. P. N. et.al.

ISSN eletrônico 1982-4688

DOI: $10.5380 /$ rf.v49 i1.57693 
volatility, and high emission of Volatile Organic Compounds (VOC) (ÇAKICIER et al., 2011). In contrast, water-based varnish is the product with the lowest toxicity level on the market as it is scratchresistant and easy to clean. Despite that, it may shiver wood fibbers and have low resistance to moisture, heat and solvents (ÇAKICIER et al., 2011). In addition, Copal varnish is originated from fossil and is insoluble in oil, it has considerable strength, high gloss finishing and is indicated for internal environments (FAZANO, 1989).

Understanding adhesion mechanisms on wood surfaces is essential to extend the service life of transparent film-forming coatings (MOURA; HERNÁNDEZ, 2004). One way to observe and analyse the finished surface is the use of images obtained by the Scanning Electron Microscopy (SEM). Another important tool to qualify coating is the study of the wettability of the surface by the analysis of the contact angle of the sessile drop, since films with high wettability means strong bond between the wood and the finishing (SOARES et al., 2011). According to Soares et al. (2011), the larger the contact angle, the smaller the ability of the liquid to penetrate the solid and spread through the surface layer, classifying it as hydrophobic. The more spherical the drop, the higher its hydrophobicity. This situation occurs due to the surface tension of the liquid, thus determining its hydrophobicity.

In this scenario, Cryptomeria japonica D. Don, from the order Coniferae and family Taxodiaceae, is an alternative and promising species. It has been used for planting in Brazil since it presents good physical and mechanical characteristics, fine texture, right grain, different growth rings, and transition from initial to late to abrupt late. Moreover, this species has a large proportion of latewood (CARNEIRO et al., 2009).

Therefore, the present study aimed to observe the wettability of different finishing processes, as well as the penetration of products in the wood of Cryptomeria japonica through the Scanning Electron Microscopy.

\section{MATERIALS AND METHODS}

\section{Testing Materials}

Cryptomeria japonica used in this research came from experimental plantations located in an Experimental Station of the Federal University of Paraná (UFPR), in the municipality of Rio Negro, inner region of the state of Paraná, Southern Brazil (26 $06^{\prime} \mathrm{S}$ and $49^{\circ} 48^{\prime} \mathrm{W}$, elevation of 847 meters).

The origin test of the material was installed between February and April 1980, and the specimens were about 35 years-old. The experiment consisted of 55 boards of Cryptomeria japonica, with dimensions of $3.5 \mathrm{~m}$ of length, 16 to $30 \mathrm{~cm}$ of width ranging and $2.6 \mathrm{~cm}$ of thickness. They were planned and sanded with seven grit sizes prior to the application of the products for finishing. This procedure is adopted by the Brazilian industries.

\section{Coating Procedure}

Four different treatments were applied on the samples, each one corresponding to a different product for surface finishing: Copal varnish, water-based varnish, nitrocellulose based varnish, and polyurethane varnish (PU). Each piece of wood had $65 \mathrm{~cm}$ of length and was sectioned into four parts of $16.25 \mathrm{~cm}$ each. They were paired among the different products, totaling 30 samples per varnish and 120 in total. Some samples presented only sapwood or only heartwood. Then, the procedure to apply the different varnishes started with the aid of a brush according to the instructions of the manufacturer. After the application of the sealants, the products for finishing were applied by using the dilution and coats recommended by the manufacturers.

\section{Microscopic Evaluation}

This technique was used to evaluate the interaction between the wood and substrates. The finished surfaces were observed by means of SEM images on the equipment Hitachi TM1000. Two samples per treatment were selected and resized into small fragments, which were used to observe the behavior and penetration of the products on the surfaces. These fragments were coupled to an aluminum support, and the differences between surface treatments were analyzed.

\section{Surface Wettability Tests}

In order to analyze the sessile drop, a micro syringe with distilled water was used. Ten drops of 2 $\mu \mathrm{l}$ were deposited on the same sample to analyze the wettability of the heartwood and sapwood. For each 
radial position, five tests were performed, totaling 30 samples per varnish and 120 in total. Measurements of the contact angles were made with the aid of a Kruss goniometer, in the longitudinal direction of the fibers, in two moments: $5 \mathrm{~s}$ and $25 \mathrm{~s}$. The structures were observed in a range of 100x, 200x and 1000x.

\section{Statistical Analyses}

Results of wettability were submitted to statistical analysis, obtaining average, minimum and maximum values, as well as to the Grubb's Test to evaluate the occurrence of outliers. In addition, the Bartlett test was used to verify the homogeneity of variance. When Anova indicated the occurrence of statistically significant difference, the Tukey test was used for averages comparison. All tests were performed using the statistical package Statgraphics Centurion XVI, with $95 \%$ of reliability.

\section{RESULTS}

\section{Microscopy}

PU, nitrocellulose, water based and copal film are shown in Figure 1.

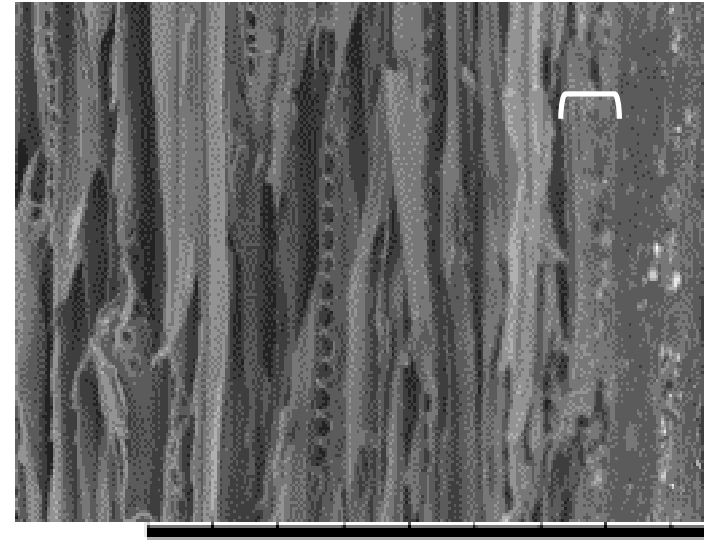

1

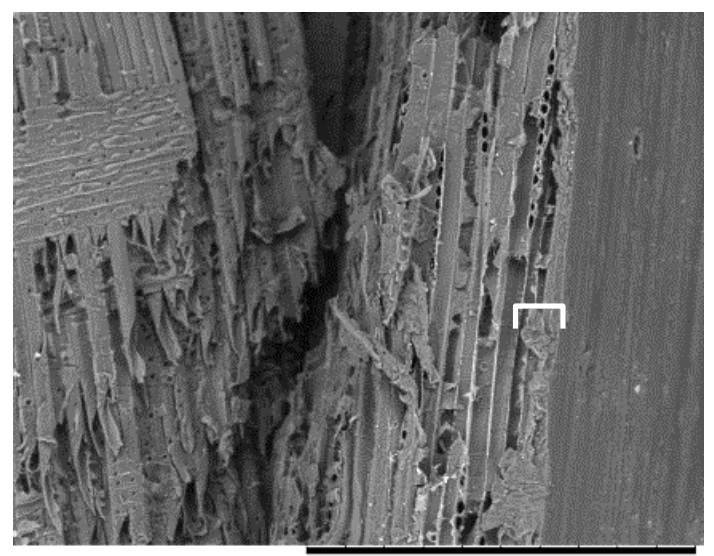

2
L $\quad$ D2.9 x200 $500 \mu \mathrm{m}$

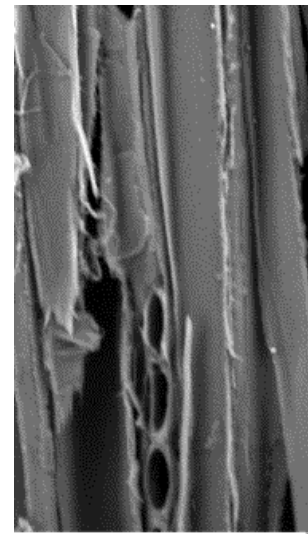

1

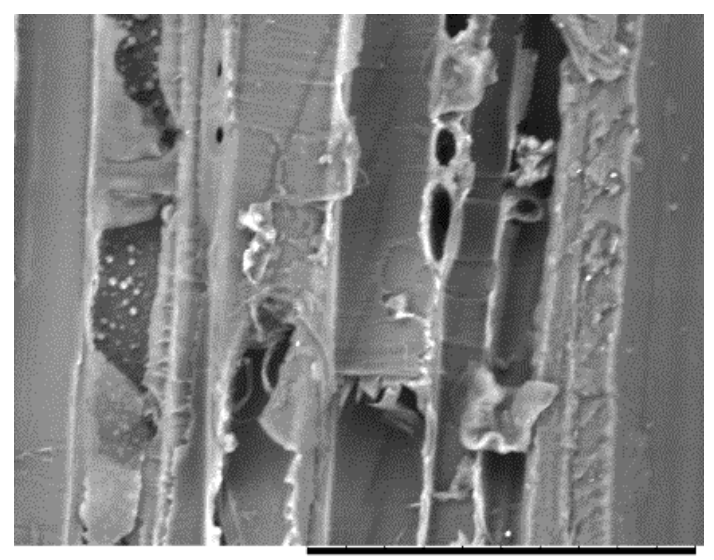

2

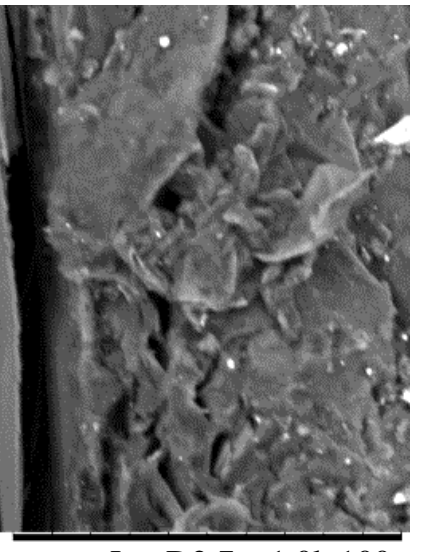

L $\quad$ D2.7 x1.0k $100 \mu \mathrm{m}$

L $\quad$ D2.9 x1.0k $100 \mu \mathrm{m}$

FLORESTA, Curitiba, PR, v. 49, n. 1, p. 117-124, jan/mar 2019.

Fonte. A. P. N. et.al. 


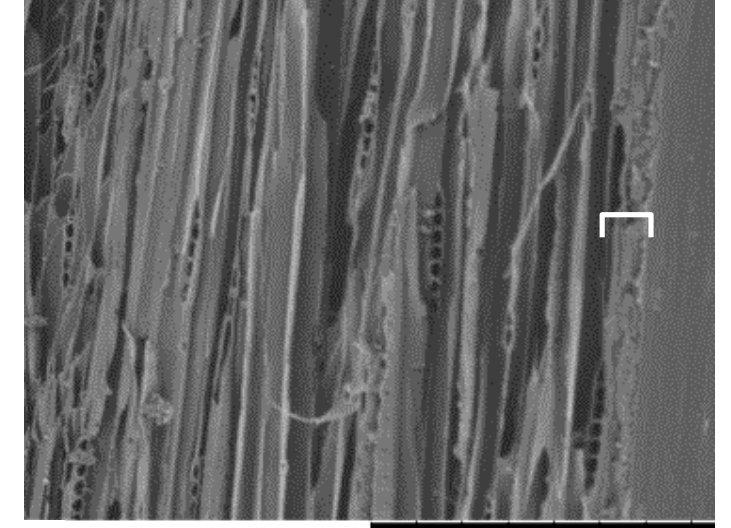

3

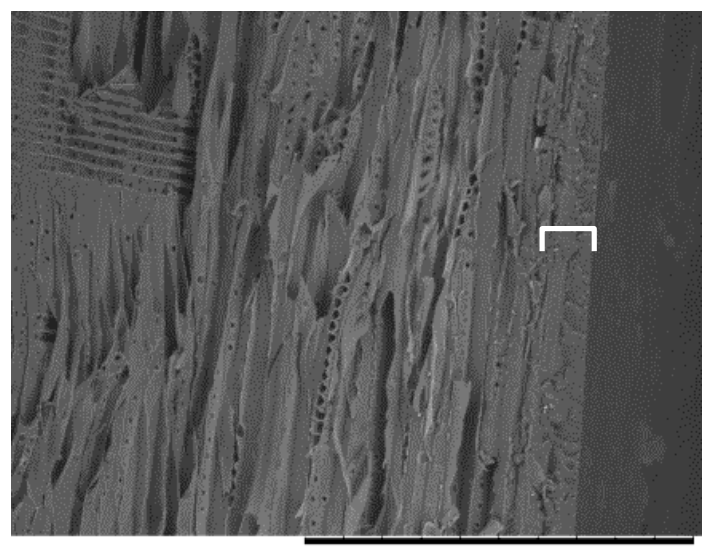

L $\quad$ D2.8 x200 $500 \mu \mathrm{m}$

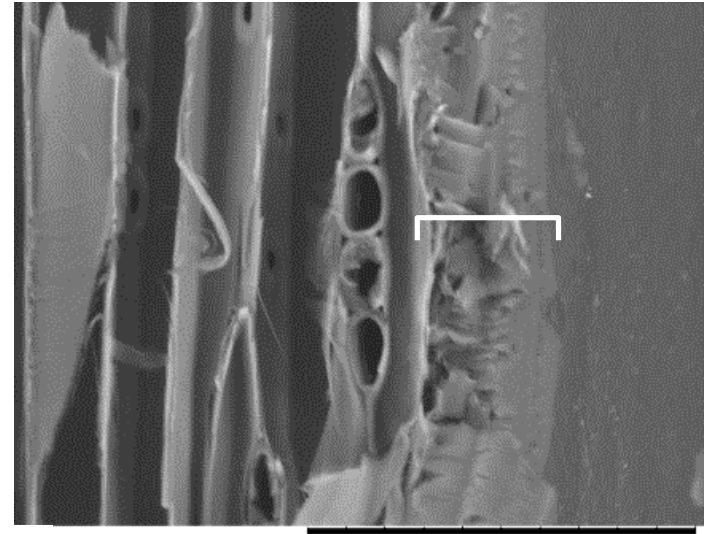

L $\quad$ D2.0 x1.0k $100 \mu \mathrm{m}$

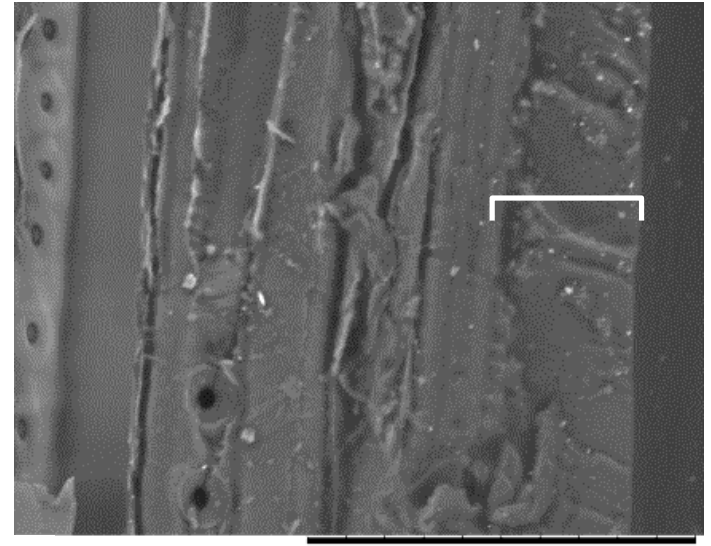

L $\quad$ D3.0 x1.0k $100 \mu \mathrm{m}$

1 - Finished surface with polyurethane; 2 - Finished surface with nitrocellulose; 3 - Finished surface with water-based varnish; 4 - Finished surface with Copal.

Figure 1. Finished surfaces with range of 200x and 1000x.

Figura 1. Superfície acabada com aumento de 200x e 1000x.

For PU, it is possible to observe that the finishing formed a homogeneous, uniform and well-defined film in relation to the substrate. The nitrocellulose film was lesser than the PU film and irregular in relation to its thickness, but it is possible to visually segregate the product from the cellular structure of the wood as it formed a film.

The water-based varnish film had thickness smaller than the PU film and similar to the Copal varnish. It was homogeneous in relation to the thickness along the analyzed part and the diffuse layer, which bonded to the substrate at several points, filling the empty spaces of the wood. In this case, it was observed that the varnish penetrated into the wood, resulting in small thickness. The copal film also had smaller thickness than the PU film. It had little homogeneity on thickness through the sample and was not presented in high definition, joining the structure of the wood in some points (Figure 1).

\section{Surface Wettability}

Table 1. Analysis of the contact angle according to the radial position.

Tabela 1. Análise do ângulo de contato em função da posição radial.

\begin{tabular}{cc}
\hline Radial position & Contact Angle $\left(^{\circ}\right)$ \\
\hline Heartwood & $79.54 \mathrm{a}$ \\
& $(15.19)$ \\
Sapwood & $77.57 \mathrm{a}$ \\
& $(14.53)$ \\
\hline P & 0.11 \\
& 0.7416 \\
\hline
\end{tabular}

Averages followed by the same letter were not significantly different. Values in parentheses refer to the coefficient of variation. 
In relation to the radial position, it is verified that the heartwood presented a contact angle value higher than the sapwood. However, no significant differences were observed between radial positions (Table 1). The coefficients of variation were considered low, and the p-value confirmed that no significant differences were reported. Regarding the treatments used, Table 2 shows the contact angles of each product and the coefficients of variation.

Table 2. Analysis of the contact angle in relation to the treatment applied to the surface.

Tabela 2. Análise do ângulo de contato em relação ao acabamento aplicado à superfície.

\begin{tabular}{cc}
\hline Treatment & Contact angle \\
Water Base & $72.12 \mathrm{c}$ \\
Copal & $(3.03)$ \\
& $92.02 \mathrm{a}$ \\
Nitrocellulose & $(3.09)$ \\
& $64.64 \mathrm{~d}$ \\
Polyurethane & $(4.55)$ \\
F & $85.44 \mathrm{~b}$ \\
$P$-valor & $(1.00)$ \\
\hline Averages & 111.24 \\
\hline
\end{tabular}

Averages followed by the same letter were not significantly different. Values in parentheses refer to the coefficient of variation.

The Copal varnish presented the highest values for contact angle of the sessile drop, followed by the PU varnish, water-based varnish and nitrocellulose varnish (Table 2). Thus, the Copal and PU varnishes present the highest hydrophobicity and, consequently, tend to be the most resistant to moisture and best in quality, having greater adhesion capacity between the wood and the finishing.

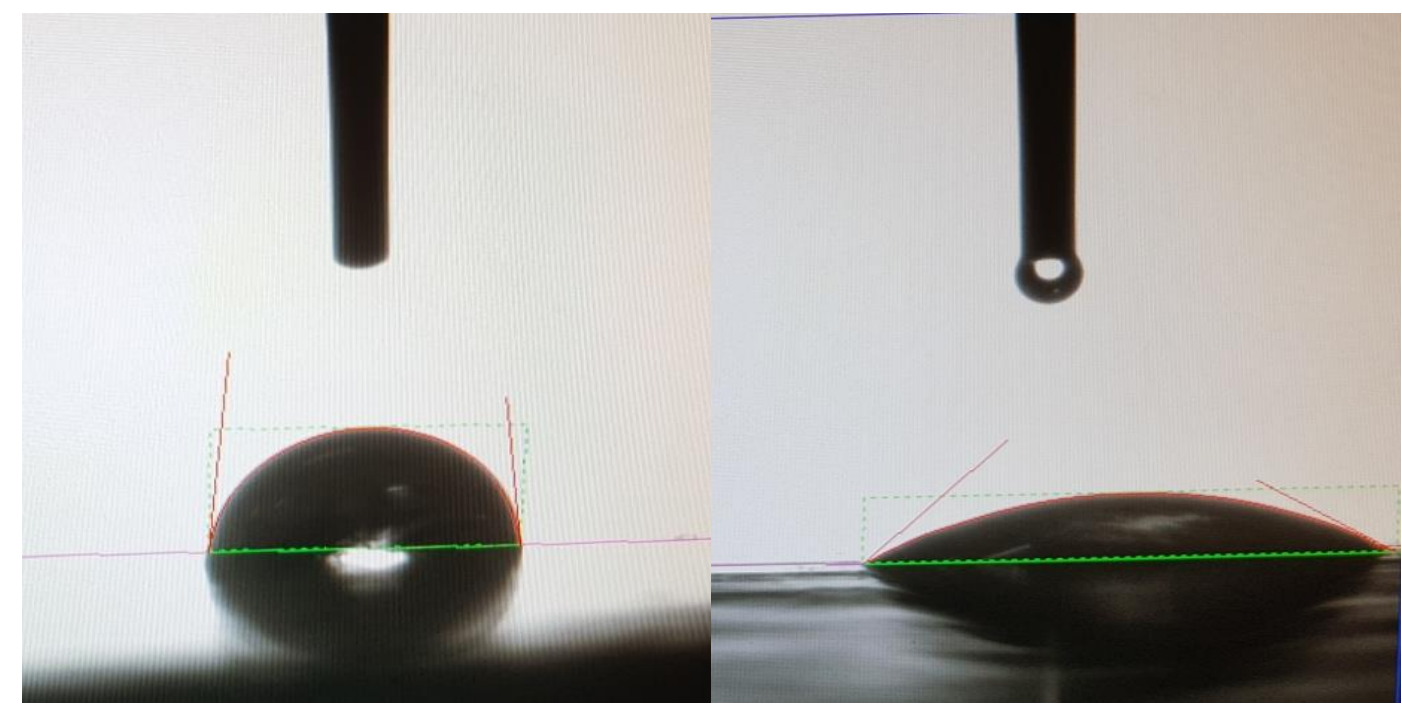

Polyurethane

Nitrocellulose

FLORESTA, Curitiba, PR, v. 49, n. 1, p. 117-124, jan/mar 2019

Fonte. A. P. N. et.al.

ISSN eletrônico 1982-4688

DOI: $10.5380 /$ rf.v49 i1.57693 


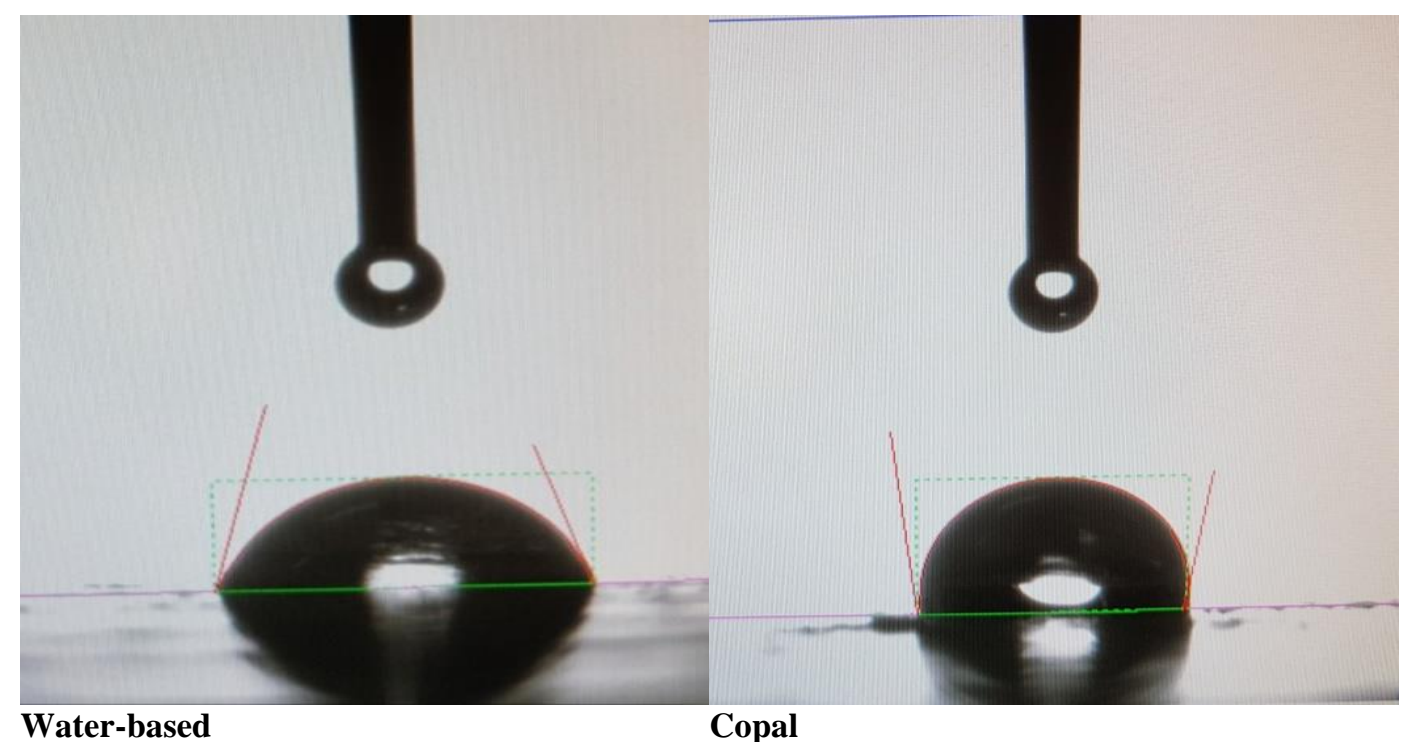

Figure 2. Drop sessile for the treatments.

Figura 2. Gota séssil para os diferentes tratamentos.

Based on Figure 2, it can be observed that the water droplet formed in the PU film and the drop formed in the Copal varnish layer had higher angles and lesser contact with the wood. The nitrocellulose varnish, the water-based varnish spread over the finishing and their contact angles were the smallest ones.

\section{DISCUSSION}

\section{Microscopy}

The presence of air bubbles in the coating film/substrate interface is a primary aspect of non-wetting systems. In this study, no air bubbles could be observed in the film/wood interface. The pressure produced by the brushes during the application of coating assured good wetting, despite the relatively high varnish viscosity (COLLETT, 1972). Tu et al. (2016) studied the morphology of the wood surface before and after the application of superhydrophobic film and verified the formation of a film on the surface of the wood of $6 \mu \mathrm{m}$ of thickness, as it was verified for the PU used in the present study (Figure 1).

\section{Surface Wettability}

Regarding the results for radial position, the heartwood had higher contact angle than the sapwood due to its natural characteristics, such as its extractive content (ferruginol and tannins, for example), which can increase the impermeability of the wood. This result was verified by Fonte et al. (2017).

The Copal varnish had high values of hydrophobicity, possibly because the products have waterproofsurface, similarly to what occurs with the stain. For PU, the high values occur due to the nature of the product, which forms a vitreous surface. In the case of the nitrocellulose varnish, the contact angle was lower than the others, possibly because the substrate diffused the drop of water used in the sessile drop or because the varnish presented products of interfacial substrates reactions (LUZ et al., 2008) (Table 2).

As observed in the SEM in the cases of PU and Copal varnishes, the finishing that presented higher contact angle also presented thick and well-separated layer of film from the substrate. Raabe et al. (2016) studied different grades of sandpaper with the application of a sealer and observed that the larger the grain of the sandpaper, the greater the contact angle, independently from the application of varnish on wood slides of curupixá, because the pores of wood become sealed with granulometry, improving the surface quality of the blades.

In the experiment of Ziglio (2014), the stain was tested for wood of Pinus sp., and it was observed that the stain had the highest contact angle among treatments during the sessile drop test, reaching between 9 and $19^{\circ}$. However, the contact angle was lower than those from other treatments of the present study (copal, nitrocellulose, water-based and PU).

According to Coutinho (2007) and Luz et al. (2008), the porosity of the surface of the wood is an aggravating factor since it contributes to the hysteresis of the contact angle or the difference between the largest 
and the smallest angle, which gives correlations between the roughness and heterogeneity of the surface analyzed, provoking changes in the local energies. According to Ziglio (2014), the roughness, and consequently porosity of the surface, has the effect of reducing the value of contact angle.

Based on the characterization techniques used in this research, it was possible to measure the uniformity, thickness and penetration of the films applied to the wood of Cryptomeria japonica. Polyurethane is indicated as a good substrate mainly for its use in internal environments, but also for external settings. The wettability test indicated the resistance of the film to moisture through the sessile drop. Thus, the higher the angle, the higher the strength, the lower the amount of water that the film absorbs, and the better the quality of the finishing.

\section{CONCLUSION}

- Water-based varnish presented a diffuse layer when observed in the SEM.

- Polyurethane varnish formed a film thicker than the other treatments on the substrate.

- Copal varnish presented the highest contact angle, and nitrocellulose varnish formed the smallest contact angle.

- Copal varnish and polyurethane showed higher hydrophobicity and higher resistance to moisture.

- The products that showed the best performance were the polyurethane and Copal varnishes.

\section{REFERENCES}

ÇAKICIER N., KORKUT S., KORKUT SEVIM D. Varnish Layer hardness, scratch resistance, and glossiness of various wood species as affected by heat treatment. BioResouces. V. 6, n. 2: 1648 - 1658. 2011.

COElho, C. L., CARVAlho, L. M., MARTins, J. M., COSTA, C. A., MASSON, D., MÉAUSOONE, P. J. Method for evaluating the influence of wood machining conditions on the objective characterization and subjective perception of a finished surface. Wood science and technology. V. 42, n. 3, p. 181-195, 2008.

COLLETT, B. M. A review of surface and interfacial adhesion in wood science and related fields. Wood science and technology. V. 6. p. 1- 42. 1972.

COUTINHO M. P. Influência da morfologia da superfície na molhabilidade do titânio comercialmente puro. Instituto Militar de Engenharia, Rio de Janeiro. 2007.

CSANÁDY, E.; MAGOSS, E.; TOLVAJ, L. Quality of machined wood surfaces. Springer. p. 183-236. 2015.

DOBNER JÚNIOR M., TRAZZI P. A., HIGA A. R Dendroecologia de um povoamento de Cryptomeria japonica (L.F.) Don. com 25 anos de idade no Sul do Brasil. Ciência Florestal. V. 24, n. 2. p.413-420. 2014.

FAZANO C. A. T. V. Tintas: Métodos de controle de pinturas e superfície. Brasil. Hemus. 1989.

FONTE, A. P. N.; TRIANOSKI, R.; IWAKIRI, S.; ANJOS, R. A. M.. Physical and chemical properties of heartwood and sapwood of Cryptomeria japonica. Revista de Ciências Agroveterinárias (Journal of Agroveterinary Sciences), v. 16, n. 3, p. 277-285, 2017.

LUZ A. P., RIBEIRO S., PANDOLFELLI V. C. Artigo de revisão: Uso da molhabilidade na investigação do comportamento de corrosão de materiais refratários. Cerâmica. V. 54, n. 330. p.174-183. 2008.

RAABE J., DEL MENEZZI C., GONÇALEZ J. Surface Evaluation of Micropholis venulosa Decorative veneers. Floresta e Ambiente. V. 24. 2016.

ROWELL R. M. Handbook of Wood Chemistry and Wood Composites, Second Edition. CRC Press, New York. 2012.

SOARES A. C., OLIVEIRA R. M., BRISOLARI A., SALES A., GONÇALVES D. Molhabilidade em amostras de Araucaria angustifolia e Pinus elliottii após tratamento térmico e envelhecimento. Scientia Forestalis. V. 39. p. 447-456. 2011.

SOFUOĞLU, S. D.; KURTOĞLU, A. Some machining properties of 4 wood species grown in Turkey. Turkish journal of Agriculture and Forestry. V. 38, n. 3, p. 420-427. 2014.

FLORESTA, Curitiba, PR, v. 49, n. 1, p. 117-124, jan/mar 2019

Fonte. A. P. N. et.al.

ISSN eletrônico 1982-4688

DOI: $10.5380 /$ rf.v49 i1.57693 
SOUZA M. O. A, SILVA J. C., DELlA LUCIA R. M., EVANGEliSTA W. V.. Avaliação da madeira de Eucalyptus camaldulensis Dehnh e Eucalyptus urophylla S.T. Blake em ensaios de usinagem, visando a produção moveleira. Arvore. V. 33. p. 751 - 758. 2009.

TU, K.; WANG, X.; KONG, L.; CHANG, H.; LIU, J. Fabrication of robust, damage-tolerant superhydrophobic coatings on naturally micro-grooved wood surfaces. RSC Advances, v. 6, n. 1, p. 701-707, 2016.

WATAI L. T. Tecnologia básica em acabamentos de madeiras. 102f. 1995.

WILLIAMS S. R. General Technical Report FPL-GTR-190. Wood Handbook, chapter 16: Finishing of Wood. U.S. Department of Agriculture, Forest Service, Forest Products. Madison. 2010.

ZIGLIO, A. C.; GONÇALVES, D. On the use of capsaicin as a natural preservative against fungal attack on Pinus sp. and Hymenaea sp. woods. Materials Research, v. 17, n. 1, p. 271-274, 2014. 